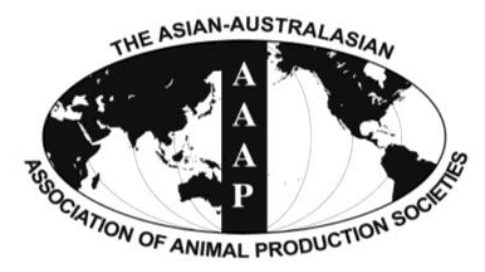

Asian Australas. J. Anim. Sci.

Vol. 26, No. 8 : 1111-1118 August 2013

http://dx.doi.org/10.5713/ajas.2013.13027

www.ajas.info

pISSN 1011-2367 elSSN 1976-5517

\title{
Milk Production, Milk Composition, Live Weight Change and Milk Fatty Acid Composition in Lactating Dairy Cows in Response to Whole Linseed Supplementation
}

\author{
Wisitiporn Suksombat*, Chayapol Meeprom, and Rattakorn Mirattanaphrai \\ School of Animal Production Technology, Institute of Agricultural Technology, Suranaree University of Technology, \\ University Avenue, Amphur Muang, Nakhon Ratchasima, 30000, Thailand
}

\begin{abstract}
The objective of this study was to determine the effects of whole linseed supplementation on performances and milk fatty acid composition of dairy cows. Thirty six Holstein Friesian crossbred lactating dairy cows were blocked by milking days first and then stratified random balanced for milk yields and body weight into three groups of 12 cows each. The control group received $300 \mathrm{~g}$ of palm oil. The second group was supplemented with $344 \mathrm{~g} / \mathrm{d}$ of top-dressed whole linseed plus $150 \mathrm{~g}$ of palm oil and the third group was supplemented with $688 \mathrm{~g} / \mathrm{d}$ of top-dressed whole linseed. All cows also received ad libitum grass silage (Brachiaria ruziziensis), had free access to clean water and were individually housed in a free-stall unit and individually fed according to treatments. Residual feeds were collected on 2 consecutive days weekly and at the end of the experiment. Feed samples were pooled to make representative samples for proximate and detergent analyses. Daily milk yields were recorded. Milk samples were collected on 2 consecutive days weekly. Live weights were recorded at the start and at the end of the experiment. Milk samples were taken on $\mathrm{d} 56$ of the experiment and subjected to milk fatty acid composition. The results showed no statistical significant differences in intakes, live weight change, milk yields and milk compositions, however, C18:1, C18:3 and unsaturated FAs were increased while saturated FAs were reduced by whole linseed supplementation. It is recommended that the addition of $300 \mathrm{~g} / \mathrm{d}$ oil from whole linseed could be beneficial to lactating dairy cows in early lactation. (Key Words: Whole Linseed, Milk Production, Milk Composition, Milk Fatty Acids, Dairy Cows)
\end{abstract}

\section{INTRODUCTION}

Linseed, also known as flaxseed, is a seed obtained from the flaxplant (Linum usitatissimum). The oil in linseed contains high levels of $\alpha$-Linoleic acid (a particular form of Omega-3 fatty acid), it is used as a nutritional supplement. The $\alpha$-linolenic acid (ALA) in flaxseed oil is suitable for cooking, as it can withstand temperatures up to $177^{\circ} \mathrm{C}$ for two hours. Regular flaxseed oil contains between $52 \%$ and 63\% ALA (C18:3 n-3). Studies (Ramon et al., 2000; Brouwer et al., 2004) have shown a relationship between ALA and an increased risk of prostate cancer. This risk was found to be irrespective of source (e.g., meat, vegetable oil; De Stéfani et al., 2000). Alternatively, at least one meta analysis has found a weak protective association between dietary ALA intake and prostate cancer risk (Simon et al., 2009). High levels of polyunsaturated fatty acids

\footnotetext{
* Corresponding Author: Wisitiporn Suksombat. Tel: +66-44224152, Fax: +66-44-224150, E-mail: wisitpor@sut.ac.th Submitted Jan. 11, 2013; Accepted Mar. 12, 2013; Revised Mar. 27, 2013
}

(particularly eicosapentaenoic C20:5 (EPA) and docosahexaenoic C22:6 (DHA) acids) are thought to protect against cardiovascular disease. There is some evidence that $\alpha$-linolenic acid (C18:3 n-3) can be elongated and desaturated by mammalian enzyme systems to produce small amounts of C20:5 and C22:6.

Many papers were published during the last 2-3 decades which describe FA profile of the milk from cows fed on different types of diets using different sources of fats and FA (Glasser et al., 2008; Moallem, 2009; Petit and Côrtes, 2010). However, despite the large amount of data published in a number of reviews, no clear conclusions have yet been drawn on the way in which the factors depending on feeding or animals influence milk fat and milk FA. Milk fat contains over 400 individual fatty acids and their isomers. Cow milk contains large amounts of SFA, particularly C14:0 and C16:0, which determine physiological dysfunctions including higher plasma cholesterol, and small amounts of MUFA, PUFA and omega-3 fatty acids with beneficial effects on human health. The problem is how to 
modify milk FA profile to make it suitable for human health. One solution is to feed whole oleaginous plants or oils from them to the cows. Canola oil and flaxseeds oil may influence milk FA level as follows: i) decrease SFA, ii) increase UFA, iii) increase the proportion of the conjugated linoleic acid (CLA) and of the $\alpha$-linolenic acid, and iv) decrease the FA omega 6 to FA omega 3 ratio. These possible changes rely on the very high level of the canola oil in C18:1 (50 to 55\%), particularly C $18: 1 \mathrm{n}-9$ and of the flaxseeds oil in C18:3 (40 to 45\%), particularly C 18:3 n-3.

Health-conscious consumers are interested in buying dairy products that are rich in mono- and polyunsaturated fatty acids. Dietary saturated fatty acids are perceived to be less healthy than polyunsaturated fatty acids. For example, myristic (C14:0) and palmitic (C16:0) acids have been demonstrated to have undesirable hypercholesterolemic effects and to increase the risk of coronary heart disease (Berner, 1993). On the other hand, conjugated linoleic acid and the long-chain polyunsaturated fatty acids, especially linoleic (C18:2n-6) and $\alpha$-linolenic (C18:3n-3), have anticarcinogenic (Parodi, 1997) and potentially cardioprotective roles in humans (Massaro et al., 1999). As a result, there has been a great deal of interest in manipulating the fatty acid profile of milk fat to respond to consumers' concerns.

Flaxseed contains a high oil level $(40 \%$ of total seed weight) with a-linolenic acid constituting approximately $55 \%$ of oil's total fatty acids (Mustafa et al., 2002; Petit, 2002, 2003). Research has shown several health benefits of omega-3 fatty acids (including $\alpha$-linolenic acid) to humans including a decrease in the incidence of cancer, cardiovascular diseases, hypertension, and arthritis and an improvement in visual ability (Simopoulos, 1996; Wright et al., 1998). Moreover, diets rich in omega-3 fatty acids (including a-linolenic acid) reduce platelet aggregation, blood triglycerides and cholesterol levels and the occurrence of blood clots, and show both antithrombotic and anti-inflammatory effects (Nash et al., 1995; Simopoulos, 1996). Reducing concentrations of C12:0 to C16:0, and replacing them with mono- and polyunsaturated fatty acids, particularly $\mathrm{C} 18: 3 \mathrm{n} 3$, could be beneficial for consumer acceptance of milk fat. Feeding cows a supplement such as flaxseed could therefore be a natural feeding option to consider when looking at modification of milk fatty acid profile. The present study aimed to determine the effect of whole linseed supplementation to lactating dairy cows on performance and fatty acid composition in milk.

\section{MATERIALS AND METHODS}

\section{Animals and treatments}

Thirty six Holstein Friesian crossbred lactating dairy cows, averaging $32 \pm 5 \mathrm{~d}$ in milk, $17.0 \pm 0.8 \mathrm{~kg}$ of milk and $435 \pm 12 \mathrm{~kg}$ body weight, were blocked by milking days first and then stratified random balanced for milk yields and body weight into three groups of 12 cows each. The first group (control) received approximately $8 \mathrm{~kg}$ of $21 \% \mathrm{CP}$ concentrate plus $300 \mathrm{~g}$ of palm oil. The second group was fed the same basal diet as the control group and supplemented with $344 \mathrm{~g} / \mathrm{d}$ of top-dressed whole linseed plus $150 \mathrm{~g}$ of palm oil and the third group was fed the same basal diet as the control group and supplemented with 688 $\mathrm{g} / \mathrm{d}$ of top-dressed whole linseed. Whole linseed contained $43.7 \%$ fat, thus the supplementation of 344 and $688 \mathrm{~g} / \mathrm{d}$ of whole linseed provided 150 and $300 \mathrm{~g} / \mathrm{d}$ of linseed oil, respectively. Palm oil was added to balance the energy concentration in the diets. All cows also received ad libitum grass silage (Brachiaria ruziziensis; $50 \mathrm{~d}$ cutting age), had free access to clean water and were individually housed in a free-stall unit and individually fed according to treatments. The experiment lasted for 10 weeks with the first $2 \mathrm{wks}$ as the adjustment period, followed by 8 wks of measurement period.

\section{Measurements, sample collection, and chemical analysis}

Residual feeds were weighed for two consecutive days of each period and samples were taken and dried at $60^{\circ} \mathrm{C}$ for $48 \mathrm{~h}$. At the end of the experimental period, feed samples were composited and subsamples were taken for further chemical analysis. Samples were ground through a 1 $\mathrm{mm}$ screen and subjected to proximate analysis. The crude protein content was determined by Kjeldahl analysis (AOAC, 1998). Ether extract was determined by using petroleum ether in a Soxtec System (AOAC, 1998). Neutral detergent fiber and acid detergent fiber were determined by using the method described by Van Soest et al. (1991), adapted for Fiber Analyzer. Chemical analysis was expressed on the basis of the final DM.

Cows were milked twice daily at 05.00 and $15.00 \mathrm{~h}$ and milk yields were recorded for each cow. Milk samples (evening and morning) were collected at each milking for two consecutive days weekly and stored at $4^{\circ} \mathrm{C}$ with a preservative (bronopol tablet; D\&F Control System, San Ramon, CA, USA) until analyzing for fat, protein, lactose and solid-not-fat contents using a Milko-Scan S50 analyzer (Tecator, Denmark). All cows were weighed at the start and end of the experiment.

\section{Milk fatty acid analysis}

Milk samples were collected from individual cows on d 56 of the experiment. Milk samples from each period were centrifuged at $2,000 \times \mathrm{g}$ to fat cake and extraction. Lipid extraction was that of the procedures described by Hara and Radin (1978), using a volume of $18 \mathrm{ml}$ of hexane and isopropanol (3:2, vol/vol)/g of fat cake. After vortexing, a 
sodium sulfate solution $\left(6.7 \% \mathrm{NaSO}_{4}\right.$ in distilled $\left.\mathrm{H}_{2} \mathrm{O}\right)$ was added at a volume of $12 \mathrm{ml} / \mathrm{g}$ of fat cake. The hexane layer was transferred to a tube containing $1 \mathrm{~g}$ of $\mathrm{NaSO}_{4}$ and the hexane layer was removed after $30 \mathrm{~min}$ and then stored at $20^{\circ} \mathrm{C}$ until methylation.

Fatty acid methyl esters (FAME) were prepared by procedure described by Ostrowska et al. (2000). The procedure briefly involved that approximately $30 \mathrm{mg}$ of the extracted oil was placed into a $15 \mathrm{ml}$ reaction tube fitted with a teflon-lined screw cap. $1.5 \mathrm{ml}$ of $0.5 \mathrm{M}$ sodium hydroxide in methanol was added. The tubes were flushed with nitrogen, capped, heated at $100^{\circ} \mathrm{C}$ for 5 min with occasional shaking and then cooled to room temperature. 1 $\mathrm{ml}$ of C17:0 internal standard ( $2 \mathrm{mg} / \mathrm{ml}$ in hexane) and $2 \mathrm{ml}$ of $14 \%$ boron trifluoride in methanol were added and heated at $100^{\circ} \mathrm{C}$ for $5 \mathrm{~min}$ with occasional shaking. After methylation was completed, $10 \mathrm{ml}$ of deionized water was added. The solution was transferred to a $40 \mathrm{ml}$ centrifuge tube and $5 \mathrm{ml}$ of hexane was added for FAME extraction. The solution was centrifuged at $2,000 \times \mathrm{g}$, at $10^{\circ} \mathrm{C}$ for 20 min and then the hexane layer was dried over sodium sulfate and was taken into vial for analysis by gas chromatography (GC) (Hewlett Packard GC system
HP6890 A; Hewlett Packard, Avondale, PA) equipped with a $100 \mathrm{~m} \times 0.25 \mathrm{~mm}$ fused silica capillary column (SP2560, Supelco Inc, Bellefonte, PA, USA). Injector and detector temperatures were $240^{\circ} \mathrm{C}$. The column temperature was kept at $70^{\circ} \mathrm{C}$ for $4 \mathrm{~min}$, then increased at $13^{\circ} \mathrm{C} / \mathrm{min}$ to $175^{\circ} \mathrm{C}$ and held at $175^{\circ} \mathrm{C}$ for $27 \mathrm{~min}$, then increased at $4^{\circ} \mathrm{C} / \mathrm{min}$ to $215^{\circ} \mathrm{C}$ and held at $215^{\circ} \mathrm{C}$ for $31 \mathrm{~min}$.

\section{Statistical analysis}

Measurements of intake, milk production, milk composition, milk fatty acids and body weight change were analyzed by ANOVA for a randomized complete block design using the Statistical Analysis System (SAS, 1996). Differences between treatment means were statistically compared using Least Significant Differences (Steel and Torrie, 1980)

\section{RESULTS AND DISCUSSION}

Chemical composition of feeds is presented in Table 1. The crude fat content and energy values of grass silage were low. This is probably because forage was harvested at a more mature stage (50 d cutting age) and, consequently,

Table 1. Chemical composition of concentrate and grass silage used in the experiment

\begin{tabular}{|c|c|c|c|c|}
\hline$\%$ Dry matter & Concentrate & Grass silage & Palm oil & Whole linseed \\
\hline Dry matter & 92.13 & 26.37 & - & 91.70 \\
\hline Crude protein & 21.24 & 7.52 & - & 21.34 \\
\hline Crude fat & 3.92 & 2.13 & 99.00 & 43.70 \\
\hline Ash & 8.56 & 10.08 & - & 3.30 \\
\hline Crude fiber & 12.31 & 29.16 & - & 6.21 \\
\hline Non fiber carbohydrate & 35.03 & 28.18 & - & 3.15 \\
\hline Neutral detergent fiber & 37.69 & 53.28 & - & 36.20 \\
\hline Acid detergent fiber & 15.64 & 35.37 & - & 22.30 \\
\hline Acid detergent lignin & 3.92 & 4.73 & - & 4.27 \\
\hline NDIN & 1.03 & 0.19 & - & 1.23 \\
\hline ADIN & 0.42 & 0.16 & - & 0.48 \\
\hline $\operatorname{TDN}_{1 X}(\%)^{1}$ & 65.80 & 56.50 & 178.20 & 71.98 \\
\hline $\mathrm{DE}_{\mathrm{P}}(\mathrm{Mcal} / \mathrm{kg})^{2}$ & 3.04 & 2.57 & 5.06 & 5.11 \\
\hline $\mathrm{ME}_{\mathrm{P}}(\mathrm{Mcal} / \mathrm{kg})^{3}$ & 2.63 & 2.14 & 5.06 & 4.71 \\
\hline $\mathrm{NE}_{\mathrm{LP}}(\mathrm{Mcal} / \mathrm{kg})^{4}$ & 1.66 & 1.31 & 4.05 & 3.12 \\
\hline$d g \mathrm{DM}^{5}$ & 65.80 & 46.20 & - & - \\
\hline$d g \mathrm{CP}^{5}$ & 67.50 & 53.10 & - & - \\
\hline
\end{tabular}

NDIN = Neutral detergent insoluble nitrogen; ADIN = Acid detergent insoluble nitrogen; $d g \mathrm{DM}=$ Effective degradability of dry matter; $d g \mathrm{CP}=\mathrm{Effective}$ degradability of crude protein; ${ }_{1 \mathrm{x}}=$ at maintenance level; $\mathrm{P}=$ at production level; $\mathrm{NE}_{\mathrm{LP}}=$ Net energy for lactation at production level $(\mathrm{NRC}, 2001)$.

${ }^{1} \mathrm{TDN}_{1 \mathrm{X}}(\%)=$ tdNFC+tdCP+(tdFA $\left.\left.\times 25.25\right)+\mathrm{tdNDF}-7\right)$

${ }^{2} \mathrm{DE}_{\mathrm{P}}(\mathrm{Mcal} / \mathrm{kg})=\left(\left(\left(\mathrm{TDN}_{1 \mathrm{X}}-\left(\left(0.18 \times \mathrm{TDN}_{1 \mathrm{XX}}\right)-10.3\right)\right) \times \mathrm{Intake}\right) / \mathrm{TDN}_{1 \mathrm{X}}\right) \times \mathrm{DE}_{1 \mathrm{X}}$

${ }^{3} \mathrm{ME}_{\mathrm{P}}(\mathrm{Mcal} / \mathrm{kg})=\left(1.01 \times\left(\mathrm{DE}_{\mathrm{P}}\right)-0.45\right)+(0.0046 \times(\mathrm{EE}-3))$

${ }^{4} \mathrm{NE}_{\mathrm{LP}}(\mathrm{Mcal} / \mathrm{kg})=\left(0.703 \times \mathrm{ME}_{\mathrm{P}}\right)-0.19,(\mathrm{EE}>3 \%)$

$\left.{ }^{4} \mathrm{NE}_{\mathrm{LP}}(\mathrm{Mcal} / \mathrm{kg})=\left(0.703 \times \mathrm{ME}_{\mathrm{P}}\right)-0.19\right)+\left(\left(0.097 \times \mathrm{ME}_{\mathrm{P}}\right) / 97\right) \times(\mathrm{EE}-30),(\mathrm{EE}>3 \%)$

${ }^{5}$ Obtained from nylon bag technique (Ørskov and McDonald, 1981).

Ingredient composition of concentrate: $32 \%$ cassava distillers dried meal, $20 \%$ soybean meal, $17.5 \%$ corn distillers dried grains with solubles, $10 \%$ rice bran, $10 \%$ wheat bran, $8 \%$ molasses, $2.5 \%$ mineral and vitamin mix.

Mineral and vitamin mix: provided per kg of concentrate: vitamin A, 5,000 IU; vitamin $\mathrm{D}_{3}, 2,200$ IU; vitamin E, 15 IU; Ca 8.5 g; P 6 g; K 9.5 g; Mg 2.4 g; Na 2.1 g; Cl 3.4 g; S 3.2 g; Co 0.16 mg; Cu 100 mg; I 1.3 mg; Mn 64 mg; Zn 64 mg; Fe 64 mg; Se 0.45 mg. 
resulting in low DM and CP degradability (46.2 and 53.1\%, respectively). Fatty acid composition of feeds is given in Table 2. Grass silage was rich in C16:0 while concentrate was rich in C18:1. Palm oil was rich in C16:0 and C18:1 whereas whole linseed was rich in $\mathrm{C} 18: 3, \mathrm{C} 18: 1$ and $\mathrm{C} 18: 2$. DM intakes of the experimental cows were similar ( $p>0.05)$ while CP and net energy for lactation (NELP) intakes of supplemented groups were significantly higher $(\mathrm{p}<0.05)$ than the control group (Table 3). CP intakes increased with increasing WLS supplementation and NELP intakes increased with increasing WLS/oil supplementation. Petit et al. (2005) suggested that the high-oil seed in the diet might depress the DM intake; however, addition of FA from oilseeds (approximately $30 \mathrm{~g} / \mathrm{kg} \mathrm{DM}$ ) has no effect on DM intake (Allen, 2000). Martin et al. (2008) concluded that lactating dairy cows fed diet supplemented with linseed oil had significantly lower DM intake compared to the control diet, however, no negative effects were found as cows were supplemented with crude linseed or extruded linseed.

In general, whole linseed is readily accepted by dairy cows, and feeding up to $15 \%$ of the total dietary dry matter had no effect on dry matter intake of dairy cows in the early (Petit, 2002), mid (Kennelly and Khorasani, 1992; Secchiari et al., 2003), or late (Martin et al., 2008) stages of lactation. Kennelly (1996) suggested that the addition of fat to ruminant diets in the form of oilseeds would have less detrimental effects on dry matter intake due to a slower release of oil from the seed, thus resulting in no decrease in dry matter intake when feeding whole linseed. In fact, declines in dry matter intake with fat-supplemented diets appear to be related to negative effects of fats. Feeding whole (Petit et al., 2002), rolled or extruded (Doreau et al., 2009) linseed had no effect on ruminal concentrations of ammonia $\mathrm{N}$, and total and individual volatile fatty acids,
Table 2. Fatty acid composition of feeds ( $\%$ of total fatty acids)

\begin{tabular}{lrrrr}
\hline Fatty acid profile & Concentrate & Palm oil & WLS & $\begin{array}{r}\text { Grass } \\
\text { silage }\end{array}$ \\
\hline C12:0 & 32.86 & 0.23 & 0.00 & 4.29 \\
C14:0 & 13.37 & 0.51 & 0.04 & 2.87 \\
C16:0 & 12.28 & 43.44 & 3.53 & 28.23 \\
C18:0 & 2.67 & 4.66 & 7.23 & 15.34 \\
C18:1 & 18.59 & 41.91 & 20.59 & 14.62 \\
C18:2 & 11.27 & 8.63 & 18.47 & 12.28 \\
C18:3 & 0.00 & 0.32 & 49.62 & 2.27 \\
Others & 8.96 & 0.30 & 0.52 & 20.10 \\
\hline WLS & & & &
\end{tabular}

WLS = Whole linseed.

thus explaining the general lack of effect on dry matter intake.

Milk yields were not significantly increased by linseed supplementation in the present study (Table 4). The higher milk yields were published in some studies (Petit et al., 2001, Petit, 2002, Petit et al., 2004). Moallem (2009) reported that the average daily milk production was $1.2 \mathrm{~kg}$ $(2.7 \%)$ higher in the dairy cows supplemented with extruded linseed at $40 \mathrm{~g} / \mathrm{kg}$ DM compared to the control diet. However, this finding disagreed with previous studies where linseed was used in dairy cow diets (Petit et al., 2002; Ward et al., 2002; Gonthier et al., 2005). In those studies, the linseed was supplemented more than $100 \mathrm{~g} / \mathrm{kg}$ DM in the diet. Martin et al. (2008) found that milk yields of dairy cows supplemented with linseed oil was decreased while there was no negative effect on dairy cows supplemented with crude linseed or extruded linseed. Soita et al. (2003) found no difference in milk yields of cows in the early stage of lactation fed a diet of $1.0 \%$ whole linseed and those fed no linseed. On the other hand, dairy cows in the early stage of lactation fed $9.6 \%$ of whole linseed in the

Table 3. Effects of whole linseed supplementation on $\mathrm{DM}, \mathrm{CP}$ and $\mathrm{NE}_{\mathrm{LP}}$ intakes of dairy cows

\begin{tabular}{|c|c|c|c|c|c|}
\hline Intake & Control (300 g PO/d) & $344 \mathrm{~g} \mathrm{WLS}+150 \mathrm{~g} \mathrm{PO} / \mathrm{d}$ & $688 \mathrm{~g} \mathrm{WLS} / \mathrm{d}$ & SEM & p-value \\
\hline \multicolumn{6}{|l|}{$\mathrm{DM}(\mathrm{kg})$} \\
\hline Concentrate & 7.37 & 7.37 & 7.37 & & \\
\hline Grass silage & 6.24 & 6.43 & 6.14 & 0.23 & 0.54 \\
\hline PO/WLS & 0.30 & 0.49 & 0.69 & & \\
\hline Total & 13.91 & 14.29 & 14.20 & 0.25 & 0.52 \\
\hline \multicolumn{6}{|l|}{$\mathrm{CP}(\mathrm{g} / \mathrm{d})$} \\
\hline Concentrate & 1,565 & 1,565 & 1,565 & & \\
\hline Grass silage & 469 & 484 & 462 & 15.28 & 0.56 \\
\hline PO/WLS & 0 & 73 & 147 & & \\
\hline Total & $2,035^{\mathrm{c}}$ & $2,122^{\mathrm{b}}$ & $2174^{\mathrm{a}}$ & 15.58 & 0.03 \\
\hline \multicolumn{6}{|l|}{$\mathrm{NE}_{\mathrm{LP}}(\mathrm{Mcal} / \mathrm{d})$} \\
\hline Concentrate & 12.23 & 12.23 & 12.23 & & \\
\hline Grass silage & 8.17 & 8.42 & 8.04 & 0.32 & 0.56 \\
\hline PO/WLS & 1.22 & 1.68 & 2.15 & & \\
\hline Total & $21.62^{\mathrm{b}}$ & $22.33^{\mathrm{a}}$ & $22.43^{\mathrm{a}}$ & 0.30 & 0.045 \\
\hline
\end{tabular}

$\mathrm{PO}=$ Palm oil; $\mathrm{WLS}=$ Whole linseed; $\mathrm{SEM}=$ Standard error of the mean; $\mathrm{NE}_{\mathrm{LP}}=$ Net energy for lactation at production level. 
Table 4. Effects of whole linseed supplementation on milk yield, milk composition, final liveweight and live weight change

\begin{tabular}{|c|c|c|c|c|c|}
\hline Yields & Control (300 g PO/d) & $344 \mathrm{~g} \mathrm{WLS}+150 \mathrm{~g} \mathrm{PO} / \mathrm{d}$ & $688 \mathrm{~g}$ WLS/d & SEM & p-value \\
\hline $3.5 \%$ FCM $(\mathrm{kg} / \mathrm{d})$ & 18.3 & 18.8 & 19.7 & 1.01 & 0.265 \\
\hline$\%$ Fat & 3.67 & 3.79 & 3.87 & 0.25 & 0.680 \\
\hline$\%$ Protein & 2.91 & 2.97 & 3.02 & 0.17 & 0.584 \\
\hline$\%$ Lactose & 4.98 & 4.86 & 4.91 & 0.32 & 0.926 \\
\hline$\%$ Solid-not-fat & 8.98 & 8.64 & 8.50 & 0.38 & 0.854 \\
\hline$\%$ Total solid & 12.65 & 12.43 & 12.37 & 0.46 & 0.893 \\
\hline Fat yield (g/d) & 653 & 682 & 720 & 56 & 0.203 \\
\hline Protein yield (g/d) & 518 & 535 & 562 & 49 & 0.981 \\
\hline Lactose yield (g/d) & 886 & 875 & 913 & 73 & 0.742 \\
\hline Solid-not-fat yield (g/d) & 1,598 & 1555 & 1581 & 106 & 0.738 \\
\hline Total solid yield (g/d) & 2,252 & 2237 & 2301 & 131 & 0.715 \\
\hline Initial live weight (kg) & 432 & 431 & 435 & 12.3 & 0.638 \\
\hline Final live weight (kg) & 446 & 441 & 457 & 13.6 & 0.827 \\
\hline LW change $(\mathrm{g} / \mathrm{d})$ & +250 & +179 & +393 & 106 & 0.835 \\
\hline
\end{tabular}

PO = Palm oil; WLS = Whole linseed; SEM = Standard error of the mean; FCM = Fat-corrected-milk.

dietary dry matter had a $8.1 \%$ decrease in milk yield compared with those fed a control diet with no linseed (Khorasani and Kennelly, 1994). Whole linseed intake was increased in short-term experiments (Petit et al., 2004) and milk production of cows in the early stage of lactation was decreased (Khorasani and Kennelly, 1994) although there was no difference in long-term experiments (Petit, 2002; Petit and Benchaar, 2007).

Inclusion of whole linseed in the diet of dairy cows had no effect on milk fat concentration and milk fat yield (Table 4). Feeding $10.4 \%$ of whole linseed to dairy cows in the early stage of lactation (Petit, 2002) and $1.8 \%$ of whole linseed to those in the late stage of lactation (Secchiari et al., 2003) had no effect on milk fat concentration and milk fat yield compared with cows fed a diet with no linseed. Milk fat concentration of dairy cows in the early stage of lactation fed diets of $9.7 \%$ whole linseed was similar to that of cows fed a control diet with no added fat but $4 \%$ fatcorrected milk yield and milk fat yield were higher (Petit et al., 2004). Inclusion of whole linseed in the diet of dairy cows in the mid stage of lactation at levels ranging from 5 to $15 \%$ (Kennelly and Khorasani, 1992) and at $11.1 \%$ (Petit et al., 2009) of the total dry matter had no effect on fat percentage (range 3.4 to $3.6 \%$ and 3.96 to $4.06 \%$, respectively) and milk fat yield. Similar results were observed for dairy cows in the early stage of lactation fed diets of $1.0 \%$ (Soita et al., 2003), 10.0\% (Khorasani and Kennelly, 1994), and $11.4 \%$ (Petit and Benchaar, 2007) whole linseed and cows in the late stage of lactation fed diets of $12.4 \%$ whole linseed (Martin et al., 2008) compared with cows fed a control diet with no linseed. In contrast, dairy cows in the mid stage of lactation fed diets of 5, 10 and $15 \%$ of whole flaxseed were higher milk fat concentrations than those fed a control diet with no linseed although there was no difference in milk fat yield (Petit and
Gagnon, 2009).

Milk protein concentration and milk protein yield were not affected by linseed supplementation (Table 4). Feeding diets of 7 to $12.4 \%$ whole untreated linseed to dairy cows in the early stage of lactation had no effect on milk protein concentration compared with feeding a control diet with no linseed (Khorasani and Kennelly, 1994; Petit et al., 2004; Martin et al., 2008), increased by $3.8 \%$ (Petit, 2002) milk protein concentration in one study and decreased milk protein concentration by $9.1 \%$ in another study (Petit et al., 2005). Moreover, feeding diets of $9.7 \%$ whole linseed compared with calcium salts of palm oil resulted in a $5.2 \%$ increase in milk protein concentration (Petit et al., 2004). Milk protein yield increased significantly when cows in the early stage of lactation were fed a diet of 9.7 to $10.4 \%$ whole linseed as a result of higher milk yield (Petit et al., 2004) and higher milk protein concentration (Petit, 2002). Feeding diets of 5 to $15 \%$ whole linseed to cows in the mid stage of lactation had no effect on milk protein concentration and milk protein yield (Petit and Gagnon, 2009; Petit et al., 2009) and similar results were obtained when cows in the early stage of lactation were fed diets of $1 \%$ (Soita et al., 2003) and $11.4 \%$ (Petit and Benchaar, 2007) whole linseed. However, although there was no difference on milk protein yield, whole linseed inclusion in the diet of dairy cows in the mid stage of lactation at levels ranging from 5 to $15 \%$ of the total dry matter resulted in a linear decrease in milk protein concentration $3.21 \%$ for control animals compared with $3.13 \%$ for cows fed $15 \%$ linseed) with increasing level of linseed inclusion (Kennelly and Khorasani, 1992). Moreover, feeding diets of $11.8 \%$ whole linseed between weeks 20 and 30 of lactation in diets containing 16 or $18 \%$ crude protein had no effect on milk protein concentration and milk protein yield compared with feeding no linseed (Petit et al., 2005). According to 
Schingoethe et al. (1996), the effect of fat supplementation on milk protein depends on the source of fatty acids being fed. It showed that feeding diets of 12.5 to $12.7 \%$ linseed reduced microbial crude protein flow to the duodenum and microbial efficiencies (true and apparent) in dairy cows in the late stage of lactation, thus decreasing the amount of microbial protein supplied for milk protein synthesis (Gonthier et al., 2004). Differences in the basal diets may also explain the discrepancies among studies as different sources of forage were used and various ratios of forage to concentrate.

The present study found no effect of whole linseed supplementation on lactose content and lactose yield (Table 4). The effect of feeding linseed on milk lactose concentration was unclear. Feeding diets of whole linseed at 7 to $10 \%$ of the dry matter to dairy cows in the early stage of lactation (Khorasani and Kennelly, 1994), up to $15 \%$ to dairy cows in the mid (Kennelly and Khorasani, 1992), and late stage of lactation (Secchiari et al., 2003; Martin et al., 2008) had no effect on milk lactose concentration compared with cows fed a control diet with no linseed. In contrast, milk lactose concentration was decreased when feeding diets of $11.8 \%$ whole linseed to dairy cows in the mid stage of lactation (Petit et al., 2005) and increased compared with feeding calcium salts of palm oil although there was no difference between feeding whole linseed and micronized soybeans (Petit, 2002).

In the present study, C18:1, C18:3 and Unsaturated FAs were increased whereas saturated FAs were decreased by whole linseed supplementation (Table 5). According to Kennelly (1996), the extent to which oilseed feeding altered the fatty acid composition of milk depended on a number of factors including: i) the degree of ruminal biohydrogenation; ii) composition of the non-lipid component of the diet; iii) influence of the lipid source on microbial fatty acid synthesis and de novo synthesis of fatty acids in the mammary gland; iv) stage of lactation; and v) intestinal and mammary gland desaturase activity. In contrast, milk from cows fed no linseed product contained usually less than $1 \%$ $\alpha$-linolenic acid (Glasser et al., 2008). These data suggest that the ability of the mammary gland to secrete $\alpha$-linolenic acid in milk is not a limiting factor in feeding strategies designed to alter milk composition, but that protection against biohydrogenation by rumen microbes is the critical point for the transfer of $\alpha$-linolenic acid from the diet to milk. In general, milk fatty acid profile was slightly improved for better human health by feeding linseed, as shown by higher concentrations of fatty acids (e.g., omega 3) recognized as being beneficial to reduce the incidence of cancer, cardiovascular diseases, hypertension, arthritis and an improvement of visual acuity (Simopoulos, 1996; Wright et al., 1998). Recently, an excellent review has been published which provides quantitative estimates of the impact of linseed and other oilseed supplements on milk fatty acid profile (Glasser et al., 2008). However, concentrations of polyunsaturated fatty acids in milk of cows fed linseed usually did not exceed 3 to $4 \%$ of total fatty acids (Kennelly, 1996). The extent of change in the concentration of fatty acids in milk was proportional to the level of inclusion of linseed in the diet (Kennelly, 1996; Petit and Gagnon, 2009). Percentages of trans-18:1 and total conjugated linolenic acid in milk fat was increased

Table 5. Effects of WLS supplementation on fatty acid composition in milk (\% of total fatty acid)

\begin{tabular}{|c|c|c|c|c|c|}
\hline Fatty acids & Control (300 g PO/d) & $344 \mathrm{~g} \mathrm{WLS}+150 \mathrm{~g} \mathrm{PO} / \mathrm{d}$ & $688 \mathrm{~g} \mathrm{WLS} / \mathrm{d}$ & SEM & p-value \\
\hline $\mathrm{C} 4: 0$ & 4.41 & 4.56 & 4.47 & 0.602 & 0.593 \\
\hline C6:0 & 2.84 & 2.73 & 2.44 & 0.396 & 0.525 \\
\hline $\mathrm{C} 8: 0$ & 1.78 & 1.63 & 1.42 & 0.294 & 0.737 \\
\hline C10:0 & 4.33 & 3.71 & 3.32 & 0.707 & 0.654 \\
\hline $\mathrm{C} 12: 0$ & 4.65 & 3.81 & 3.33 & 0.644 & 0.456 \\
\hline $\mathrm{C} 14: 0$ & 12.40 & 11.50 & 10.60 & 1.120 & 0.895 \\
\hline $\mathrm{C} 14: 1$ & 1.21 & 1.18 & 1.31 & 0.261 & 0.413 \\
\hline C16:0 & 32.70 & 29.40 & 26.80 & 2.220 & 0.693 \\
\hline C16:1 & 1.65 & 1.54 & 1.69 & 0.376 & 0.351 \\
\hline C18:0 & 7.80 & 8.91 & 9.00 & 1.390 & 0.323 \\
\hline C18:1 & $18.13^{\mathrm{c}}$ & $22.08^{\mathrm{b}}$ & $25.25^{\mathrm{a}}$ & 0.382 & 0.034 \\
\hline $\mathrm{C} 18: 2$ & 1.73 & 1.87 & 1.91 & 0.246 & 0.613 \\
\hline C18:3 & $0.23^{\mathrm{b}}$ & $0.44^{\mathrm{ab}}$ & $0.67^{\mathrm{a}}$ & 0.112 & 0.048 \\
\hline C20:0 & 0.07 & 0.07 & 0.13 & 0.069 & 0.277 \\
\hline C20:1 & 0.03 & 0.03 & 0.03 & 0.010 & 0.594 \\
\hline Others & 6.04 & 6.53 & 7.63 & 1.023 & 0.342 \\
\hline Saturated FA & $70.98^{\mathrm{a}}$ & $66.32^{\mathrm{b}}$ & $61.51^{\mathrm{c}}$ & 0.654 & 0.036 \\
\hline Unsaturated FA & $22.98^{\mathrm{c}}$ & $27.14^{\mathrm{b}}$ & $30.86^{\mathrm{a}}$ & 0.542 & 0.037 \\
\hline
\end{tabular}

PO = Palm oil; WLS = Whole linseed; SEM = Standard error of the mean. 
linearly as the amount of linseed in the diet was increased (Glasser et al., 2008). Diets with linseed oil given as extruded, micronized, or ground seeds decreased milk fat concentrations of $\mathrm{C} 6$ to $\mathrm{C} 8, \mathrm{C} 10$ to $\mathrm{C} 14$, and 16:0, and increased those of total $\mathrm{C} 18$, trans-18:1, conjugated linoleic acid, and linolenic acid more than whole seeds (Glasser et al., 2008).

Linseed is a potential alternative to fish oil as dietary source of unsaturated fatty acids. Dairy cows offered whole linseed at $72 \mathrm{~g} / \mathrm{kg}$ DM had higher milk cis-9 C18:1, C18:3n-3, MUFA and PUFA than those cows fed the control diet (Petit and Côrtes, 2010). Similar results were also found as the dairy cows fed the basal diet supplemented with extruded linseed at $28 \mathrm{~g} / \mathrm{kg}$ DM (Moallem, 2009). Fuentes et al. (2008) reported that dairy cows supplemented with 5.5\% DM extruded linseed for $90 \mathrm{~d}$ had greater C18:1 cis9, CLA, $\Omega 3$, MUFA and PUFA compared to the control diet.

\section{CONCLUSIONS}

The present study clearly indicated that supplementation of whole linseed to lactating dairy cows had no effect on milk yield and milk composition, however, C18:1, C18:3 and unsaturated fatty acids were increased and saturated fatty acids were decreased by WLS supplementation. Therefore, $300 \mathrm{~g} / \mathrm{d}$ of oil from whole linseed should be supplemented to lactating dairy cows' diets.

\section{ACKNOWLEDGEMENTS}

Authors would like to express special thanks to the Dairy Farming Promotion Organization of Thailand (DPO), the Center for Scientific and Technological Equipment for their great support. Financial support was provided by the Institute of Research and Development, Suranaree University of Technology.

The work was supported by the Institute of Research and Development, Suranaree University of Technology.

\section{REFERENCES}

Allen, M. S. 2000. Effects of diet on short-term regulation of feed intake by lactating dairy cattle. J. Dairy Sci. 83:1598-1624.

Association of official analytical chemists, 1998. Official Method of Analysis. Washington DC.

Berner, L. A. 1993. Roundtable discussion on milkfat, dairy foods, and coronary heart disease risk. J. Nutr. 123:1175-1184.

Brouwer, I. A., M. B. Katan, and P. L. Zock. 2004. Dietary alphalinolenic acid is associated with reduced risk of fatal coronary heart disease, but increased prostate cancer risk: a metaanalysis. J. Nutr. 134:919-922.

Chilliard, Y., F. Glasser, A. Ferlay, L. Bernard, J. Rouel, and M. Doreau. 2007. Diet, rumen biohydrogenation and nutritional quality of cow and goat milk fat: A review. Eur. J. Lipid Sci. Technol. 109:828-855.

De Stéfani, E., H. Deneo-Pellegrini, P. Boffetta, A. Ronco, and M. Mendilaharsu. 2000. Alpha-linolenic acid and risk of prostate cancer: a case-control study in Uruguay. Cancer Epidem. Biomark. Preven. 9:335-338.

Dhiman, T. R., L. D. Satter, M. W. Pariza, M. P. Galli, K. Albright, and M. X. Tolosa. 2000. Conjugated linoleic acid (CLA) content of milk from cows offered diets in linoleic acid. J. Dairy Sci. 83:1016-1027.

Doreau, A., A. Belot, J. Bastid, B. Riche, M. C. Trescol-Biemont, B. Ranchin, N. Fabien, P. Cochat, C. Pouteil-Noble, P. Trolliet, I. Durieu, J. Tebib, B. Kassai, S. Ansieau, A. Puisieux, J. F. Eliaou, and N. Bonnefoy-Berard. 2009. Interleukin 17 acts in synergy with B cell-activating factor to influence B cell biology and the pathophysiology of systemic lupus erythematosus. Nat. Immunol. 10:778-785.

Fuentes, M. C., S. Calsamiglia, C. Sanchez, A. Gonzalez, J. R. Newbold, J. E. P. Santos, L. M. Rodriguez-Alcala, and J. Fontecha. 2008. Effect of extruded linseed on productive and reproductive performance of lactating dairy cows. Livest. Sci. 113:144-154.

Glasser, F., A. Ferlay, and Y. Chilliard. 2008. Oilseed lipid supplements and fatty acid composition of cow milk: a metaanalysis. J. Dairy Sci. 91:4687-4703.

Gonthier, C., A. F. Mustafa, R. Berthiaume, H. V. Petit, R. Martineau, and D. R. Ouellet. 2004. Effects of feeding micronized and extruded flaxseed on ruminal fermentation and nutrient utilization by dairy cows. J. Dairy Sci. 87:1854-1863.

Gonthier, C., A. F. Mustafa, D. R. Ouellet, P. Y. Chouinard, R. Berthiaume, and H. V. Petit. 2005. Feeding micronized and extruded flaxseed to dairy cows: Effects on blood parameters and milk fatty acid composition. J. Dairy Sci. 88:748-756.

Hara, A., and N. S. Radin. 1978. Lipid extraction of tissues with a low-toxicity solvent. Anal. Biochem. 90:420-424.

Kennelly, J. J. 1996. The fatty acid composition of milk fat as influeneced by feeding oilseeds. Anim. Feed Sci. Technol. 60: 137-152.

Kennelly, J. J., and G. R. Khorasani. 1992. Influence of flaxseed feeding on fatty acid composition on cow's milk. In: Proc. 54th Flax Inst. Conf. North Dakota State Univ. Fargo. pp. 99-105.

Khorasani, R. G., and J. J. Kennelly. 1994. Influence of flaxseed on the nutritional quality of milk. Pages $127-134$ in J. Proc. 55th Flax Inst. Conf. F. Carter, ed. North Dakota State Univ. Fargo.

Martin, C., J. Rouel, J. P. Jouany, M. Doreau, and Y. Chilliard. 2008. Methane output and diet digestibility in response to feeding dairy cows crude linseed, extruded linseed or lionseed oil. J. Anim. Sci. 86:2642-2650.

Massaro, M., M. A. Carluccio, and R. De Caterina. 1999. Direct vascular antiatherogenic effects of oleic acid: a clue to the cardioprotective effects of the Mediterranean diet. Cardiologia 44:507-513.

Moallem, U. 2009. The effects of extruded flaxseed supplementation to high-yielding dairy cows on milk production and milk fatty acid composition. Anim. Feed Sci. Technol. 152:232-242.

Mustafa A. F., P. Y. Chouinard, and D. A. Christensen. 2002. Effect of micronization of flaxseed on nutrient disappearance 
in the gastrointestinal tract of steer. Anim. Feed Sci. Technol. 95: 123-132.

Nash, D. M., R. M. G. Hamilton, and H. W. Hulan. 1995. The effect of dietary herring meal on the omega-3 fatty acid content of plasma and egg yolk lipids of laying hens. Can. J. Anim. Sci. 75:247-253.

Onetti, S. G., and R. R.Grummer. 2004. Response of lactating cows to three supplemental fat sources as affected by forage in the diet and stage of lactation: a meta-analysis of literature. Anim. Feed Sci. Technol. 115:65-82.

Ostrowska, E., F. R. Dunshea, M. Muralitharan, and R. F. Cross. 2000. Comparison of Silverion high performance liquid chromatographic quantification of free and methylated conjugated linoleic acid. Lipids 35: 147-1153.

Parodi, P. W. 1997. Milk fat conjugated fatty acid: Can it help prevent breast cancer? Proc. Nutr. Soc. NZ. 22:137-149.

Petit, H. V. 2002. Digestion, milk production, and blood composition of dairy cows fed whole flaxseed. J. Dairy Sci. 85:1482-1490.

Petit, H. V., and C. Benchaar. 2007. Milk production, milk composition, blood composition, and conception rate of transition dairy cows fed different fat sources. Can. J. Anim. Sci. 87:591-600.

Petit, H. V., and N. Gagnon. 2009. Milk concentrations of the mammalian lignans enterolactone and enterodiol, milk production, and whole tract digestibility of dairy cows fed diets containing different concentrations of flaxseed meal. Anim. Feed Sci. Technol. 152:103-111.

Petit, H. V., and C. Côrtes. 2010. Milk production and composition, milk fatty acid profile, and blood composition of dairy cows fed whole or ground flaxseed in the first half of lactation. Anim. Feed Sci. Technol. 158:36-43.

Petit, H. V., R .J. Dewhurst, J. G. Proulx, M. Khalid, W. Haresign, and H. Twagiramungu. 2001. Milk production, milk composition and reproductive function of dairy cows fed different fats. Can. J. Anim. Sci. 81:263-271.

Petit, H. V., R. J. Dewhurst, N. D. Scollan, J. G. Proulx, M. Khalid, W. Haresign, H. Twagiramungu, and G. E. Mann. 2002. Milk production and composition, ovarian function and prostaglandin secretion of dairy cows fed omega-3 fats. J. Dairy Sci. 85: 889-899.

Petit, H. V., C. Germiquet, and D. Lebel. 2004. Effect of feeding whole, unprocessed sunflower seeds and flaxseed on milk production, milk composition and prostaglandin secretion in dairy cows. J. Dairy Sci. 87:3889-3898.
Petit, H. V., M. Ivan, and P. S. Mir. 2005. Effects of flaxseed on protein requirements and $\mathrm{N}$ excretion of dairy cows fed diets with two protein concentrations. J. Dairy Sci. 88:1755-1764.

Petit, H. V., N. Gagnon, P. S. Mir, R. Tsao, and S. W. Cui. 2009. Milk concentration of the mammalian lignan enterolactone, milk production, milk fatty acid profile, and digestibility in dairy cows fed diets containing whole flaxseed or flaxseed meal. J. Dairy Res. 76:257-264.

Ramon, J. M., R. Bou, S. Romea, M. E. Alkiza, M. Jacas, J. Ribes, and J. Oromi. 2000. Dietary fat intake and prostate cancer risk: a case-control study in Spain. Cancer Causes Control: CCC 11: 679-685.

Schingoethe, D. J., M. J. Brouk, K. D. Lightfield, and R. J. Baer. 1996. Lactational responses of daily cows fed unsaturated fat from extruded soy beans or sunflower seeds. J. Dairy Sci. 79: 1244-1249.

Secchiari, P., M. Antongiovanni, M. Mele, A. Serra, A. Buccioni, G. Ferruzzi, F. Paoletti, and F. Petacchi. 2003. Effect of kind of dietary fat on the quality of milk fat from Italian Friesian cows. Livest. Prod. Sci. 83:43-52.

Simon, J. A., Y. H. Chen, and S. Bent. 2009. The relation of alphalinolenic acid to the risk of prostate cancer: a systematic review and meta-analysis. Am. J. Clinic. Nutr. 89:1558S$1564 \mathrm{~S}$.

Simopoulos, A. P. 1996. The role of fatty acids in gene expression: health implications. Ann. Nutr. Metab. 40:303-311.

Soita H. W., J. A. Meier, M. Fehr, P. Yu, D. A. Christensen, J. J. Mckinon, and A. F. Mustafa. 2003. Effects of flaxseed supplementation on milk production, milk fatty acid composition and nutrient utilization by lactating dairy cows. Arch. Anim. Nutr. 57:107-116.

Statistical Analysis System, 1996. SAS User' Guide: Statistics. NC: SAS Institute.

Steel, R .G. D., and J. H. Torrie. 1980. Principles and Procedures of Statistics: a biometeric approach (2nd Ed). McGrowhill: New York.

Van Soest, P. J., J. B. Robertson, and B. A. Lewis. 1991. Methods for dietary fiber, neutral detergent fiber and non-starch polysaccharides in relation to animal production. J. Dairy Sci. 74:3583-3597.

Ward, A. T., K. M. Wittenberg, and R. Przybylski. 2002. Bovine milk fatty acid profiles produced by feeding diets containing solin, flax and canola. J. Dairy Sci. 85:1191-1196.

Wright, T., B. McBride, and B. Holub. 1998. Docosahexaenoic acid enriched milk. World Rev. Nutr. Diet. 83:160-165. 